\title{
Morphological signs of myopathy in pork that show no drastic decrease in $\mathrm{pH}$ after slaughter
}

\author{
A. A. Semenova*, T. G. Kuznetsova*, V. V. Nasonova*, S. I. Loskutov*, R. V. Nekrasov**, N. V. Bogolyubova** \\ *V. M. Gorbatov Federal Research Center for Food Systems of RAS, Moscow, Russia \\ **L. K. Ernst Federal Research Center for Animal Husbandry, Podolsk, Russia
}

Article info

Received 25.09.2021 Received in revised form 18.10 .2021 Accepted 20.10.202

V. M. Gorbatov Federal Research Center for Food Systems of RAS

Talalikhina st. 26,

Moscow, 109316, Russia.

Tel.:+7-495-676-95-11

E.mail:a.semenova@fncps.ru

L. K. Ernst Federal Research Center for Animal Husbandry, poselok Dubrovitsy, 60, Podolsk, 142132,

Moscow Region, Russia Tel.:+7-496-765-12-77.

E-mail:nekroman@mail.ru
Semenova, A. A., Kuznetsova, T. G., Nasonova, V. V., Loskutov, S. I., Nekrasov, R. V., Bogolyubova, N. V. (2021). Morphological signs of myopathy in pork that show no drastic decrease in pH after slaughter. Regulatory Mechanisms in Biosystems, 12(4), 683688. doi:10.15421/022194

High $\mathrm{pH}$ value 45 minutes after slaughter $\left(\mathrm{pH}_{45}\right)$ has so far been the most frequently used indicator to select pig carcasses with normal course of autolysis. However, in practice, this does not provide meat quality homogeneity. Therefore, carcasses with $\mathrm{pH}_{45}>6.0$ were examined for signs of myopathy, which are characteristic for PSE meat, using the histological method. To perform the study, we randomly selected 320 individuals for slaughter out of 1,059 individuals of mixed swine grown in the same conditions. After slaughter, we selected 18 fresh carcasses that demonstrated low $\mathrm{pH}_{45}$. The results of the examination of the muscular tissue $(L$. dorsi) samples revealed that pork varied in microstructural characteristics. Only $44 \%$ of the samples had no signs of myopathy: no contracture nodes and destructive changes in the muscle fibers were present. A total of $39 \%$ of the samples were identified to the muscular tissue with mildly expressed myopathy, $17 \%$ of the samples - to the muscular tissue with acute myopathy. Thus, among the carcasses with $\mathrm{pH}_{45}>$ $6.0,56 \%$ of the carcasses had signs of mild and acute myopathy, which explains quality homogeneity of meat selected using this criterion. Statistical analysis of the results suggested that the increase in the diameter of the muscle fibers of glycolytic type was related to appearance of signs of mild and acute myopathy - "giant fibers". Increase in the weight of animals is not a risk factor. The obtained results allowed us to conclude the necessity of developing new approaches to assessing meat quality immediately after the slaughter with the purpose of increasing efficiency in predicting technological properties of meat. Promising directions of developing quick methods in histology allow us to hope that such approaches may be based on the data on microstructure of fresh muscular tissue.

Keywords: muscle fibers; contracture nodes; muscle tissue; PSE; microstructure; histology.

\section{Introduction}

Pork makes up $40 \%$ of global meat consumption (Keenan, 2016). As FAO predicts, the pork production will increase to $127 \mathrm{M}$ tons around the globe. Russia, the fourth global producer of pork, has almost doubled the production in response to import prohibition, implementing domestic policy of restructuring and stimulating the industry. By 2030, production of Russian pork is planned to have increased by $10 \%$. At the same time, by 2023 , the production of pork in China is expected to return to the level of 2017, after the outbreak of African swine fever had occurred in Asia in 2018. Most of increase in pork production around the world will be the result of further transition from private farms to commercial production (OECD/FAO, 2021).

Compatibility of pork producers is mainly determined by meat quality that depends directly on health of animals. Selective programs of swine breeding, implemented in large livestock enterprises, are oriented at maximum increase in growth rates and large content of muscular tissue in the carcasses (Li et al., 2013; Shen et al., 2014). Such an approach in swine breeding has for a long time been considered the main reason for development of osteochondrosis and myopathy in animals during their life. At the age from three to five months, the immature skeleton of animals suffers from daily weight gain of approximately $1 \mathrm{~kg}$. This leads to regeneration of cartilaginous tissue and Salter-Harris fracture with proliferative reaction of the bone. In swine, increase in the content of muscular tissue in the carcass results in increased sensitivity to stress and development of myopathy. Myopathy can manifest as sudden death of animal as a result of lactic acidosis and cardiogenic shock, and also lead to production of meat with reduced consumer and technological properties. A typical example of such meat is PSE pork (Bickhardt, 1998).

Myopathy affects the most valuable parts of the pig carcasses (longissimus and muscles of the coxal part, rarer muscles of the shoulder blade, thoracic and cervical parts), imposing significant economic losses. Annual losses of the leading pork-producing countries due to PSE meat are estimated at millions of dollars (Owen et al., 2000). Furthermore, decrease in functional properties of proteins causes inappropriateness of meat for the production of certain types of goods - boiled and fermented crusts, ham, etc (Honkavaara, 1988; O’Neill et al., 2003; Eliášová et al., 2017).

Successes of scientists in the sphere of identification of genetic markers allows excludision of animals that are susceptible to PSE condition from the selective breeding programs (Barbut et al., 2008). Faults of pork which are related to disorders in the structure of the muscular tissue (myopathy) and low post-slaughter $\mathrm{pH}$ values are still common - over $45 \%$ of total number of carcasses resulting from the slaughter in some regions (Van de Perre et al., 2010; Cazedey et al., 2016). Reasons for myopathy onset should be analyzed in complex. Myopathy may be caused by different factors in animal husbandry and meat production, including stress during slaughter (Sandercock et al., 2001; Rosenvold et al., 2003; Trevisan \& Brun, 2020).

To classify pork by quality, different approaches have been proposed measuring autolysis of $\mathrm{pH}$, electroconductivity, lightness, moisture-holding capacity, etc. in different periods (Kim et al., 2014; Neethling et al., 2017). Despite the existing approaches, there is currently no universal understanding of choosing criteria of technologic appropriateness of pork for meat production (Trevisan \& Brun, 2020). At the same time, despite limi- 
ted abilities of predicting the ultimate result, high $\mathrm{pH}$ value 45 minutes after the slaughter $\left(\mathrm{pH}_{45}\right.$ over 6.0$)$ remains the most frequently used indicator to select pig carcasses right after the slaughter (Fiener, 2006; Trevisan \& Brun, 2020).

At the same time, structural-functional characteristics of the muscle fibers of swine well reflect the relationship between quality of meat in cases of histological examination of pork of different qualitative groups (PSE, NOR, DFD) (Fiedler et al., 1999). Therefore, the present study aimed at studying morphological signs of myopathy of the muscular tissue of fresh pork with high $\mathrm{pH}$ values 45 min following slaughter.

\section{Materials and methods}

The studies were performed according to the requirements of the European Convention for the Protection of Vertebrate Animals used for Experimental and other Scientific Purposes (ETS No. 123, Strasbourg, 1986). The research was approved by the bioethical commission of the V. M. Gorbatov Federal Research Center for Food Systems of the Russian Academy of Sciences (protocol No. 03/2019, dated May 31, 2019). Production premise where the study was carried out has been provided with all necessary equipment, supply and system of fodder distribution. All the animals were in the same conditions and had free access to fodders and water throughout the studies.

In our experiment, there were created all conditions to level out the influences of breed factor, system of growing and fattening, ways of transportation, pre-slaughter preparation and slaughter. For this purpose, we randomly selected piglets of hybrid population of intensely growing swine, which are broadly used in industrial swine breeding, $-1,059$ individuals of mixed piglets with mean live weight of $7.34 \pm 1.35 \mathrm{~kg}$ aged 26 days. The animals were selected, grown and fattened at the base of Ltd Selectivehybrid Center (Verkhnyaya Khava, Voronezh Oblast).

The animals were self-fed from group self-feeders; the fodders met the modern detailed norms for the age and weight characteristics of the animals, including the parameters of energetic and nutritional values ( $\mathrm{Ne}$ krasov et al., 2018). The animals were maintained and taken care of in the same way, according to the required norms (temperature, moisture, light regime and gas composition of air in the room) - within the limits of zoohygienic norms (Ovsyannikov, 1976). The growing lasted for 45 days, fattening -99 days. Thus, all the animals were in the same maintenance conditions for 144 days.

The growing young were periodically assessed for increments of live body weight. To check the growth of the piglets, we used selection (30 individuals). Slaughtered were those that reached the live weight of no less than $125 \mathrm{~kg}$. According to the experiment plan, 320 pigs (two lots or two vehicles containing 160 individuals in each) were randomly selected from the general selection and transferred for slaughter. All pre-slaughter procedures (hunger, transport, preparation of animals for slaughter) and slaughter were carried out in the identical conditions. During the slaughter, to immobilize the animals, wo-contact electric stunning was used. The slaughter was performed at the Industrial Enterprise Ltd Bogdanovskyi Meat-Packing Plant (Voronezh Oblast, Russian Federation).

Belonging of fresh carcasses to the lot was taken into account while measuring $\mathrm{pH}_{45}$ and temperature before the results of checking the hypothesis about absence of significant statistical differences between the lots. In fresh carcasses 45 minutes after slaughter, we determined $\mathrm{pH}$. Of the carcasses with $\mathrm{pH}$ above 6.0, we randomly selected 18 carcasses for histological studies. At the same time, we collected data on the weight of fresh carcasses, the diameter of the transverse section of the longissimus and thickness of bone marrow. From each right half-carcass, we sampled the muscular tissue (m. l. dorsi), fixated it and subjected to histological studies. Based on the results of the statistical analysis, we determined the degree of manifestation of myopathic changes in the samples of fresh pork with $\mathrm{pH}_{45}$ higher than 6.0 and their relationship with the characteristics of the carcasses.

The weight of fresh carcasses was determined by weighing $45 \mathrm{~min}$ after the slaughter on industrial scales of accuracy class III (mean) which were installed into the hanging rail. Thickness of the bone marrow was measured using a metal ruler above the spinous processes between the 6th and 7 th thoracic vertebrae, not taking into account the skin thickness.
The area of the transversal section of the longissimus in the region of ribs $10-11$ was determined by making a print on paper with following measurement using planimeter according to methodological recommendations (Russia, 1987). The temperature and $\mathrm{pH}$ were measured using Testo 205 device (Testo SE \& Co. KGaA, Germany, 2019). The device's inaccuracy was \pm 0.2 for measurements of $\mathrm{pH}$, and $\pm 0.4{ }^{\circ} \mathrm{C}$ for temperature. The measurements were made in the layer of the longissimus at the level of thoracic vertebrae 8-12. Values of $\mathrm{pH} 45 \mathrm{~min}\left(\mathrm{pH}_{45}\right)$ post-slaughter were measured in fresh carcasses with temperature in the muscle layer. Carcasses were considered fresh if their temperature was no lower than $35^{\circ} \mathrm{C}$. Values of $\mathrm{pH} 24 \mathrm{~h}$ after slaughter were determined in cooled carcasses with temperature no higher than $4{ }^{\circ} \mathrm{C}$. Values of $\mathrm{pH}$ and temperature were determined no less than three times, and the final result was considered the mean value of the three measurements in the conditions of differences in the results of parallel measurements equaling no more than the corresponding inaccuracy of the device. To carry out histological studies, rectangular $1.0 \times 1.5 \mathrm{~cm}$ samples (no less than 2) were cut from each sample of pork (m. l. dorsi).

The samples were fixated in $15 \%$ solution of neutral formalin. After the fixation, they were embedded in $12.5 \%$ and $25.0 \%$ solution of gelatin at the temperature of $37{ }^{\circ} \mathrm{C}$ and then in $10 \%$ solution of formalin. Preparing longitudinal and transversal sections of $15 \mu \mathrm{m}$ thickness was carried out using cryostat microtome Leika SM 1850 (Leika, Germany, 2009). For monitoring study, the longitudinal sections were stained with hematoxylin-eosin. To identify the types of muscular fibers, the transversal sections were stained with Sudan black according to the method of Saprykin \& Turbin (1997). Depending on the intensity of staining, the muscular fibers were identified to type I (glycolytic), intermediate or type II (oxidative). Longitudinal and transversal sections were studied using image analyzer Motic Images (Motik, China, 2009) with magnification x 40 from five points of view (no less than 200 fibers) in each section, the diameter of fibers was identified with the accuracy of $\pm 1.0 \mu \mathrm{m}$. The share of fibers of each type was calculated in percents as the ratio of the amount of fibers of this type to the overall number of fibers, observed from five points of view. The lengths of sarcomeres were measured at $x 400$ increase with the accuracy of $\pm 0.1 \mu \mathrm{m}$.

During the study of histological samples, we also determined the shape and the diameter of the muscular fibers, the conditions of the transversal striation and sarcolemma, length of sarcomeres. We also detected nodes and stripes of contraction and determined their sizes.

The samples of the muscle tissue, extracted and fixated in fresh condition, were studied for and classified according to the presence of morphological signs of myopathy to three groups: samples with no signs of myopathy; samples with mildly expressed myopathy; samples with acute myopathy. For this purpose, we used the known morphological signs of myopathy (Sosnicki, 1987; Schubert-Schoppmeyer et al., 2008) which occur in the structure of the muscle tissue after slaughter of animals, noting presence and signs of nodes (stripes) of contraction-so called "giant fibers".

The experimental data were analyzed using $\mathrm{R}$ software 4.1.0, (https://cran.r-project.org/bin/windows/base). Statistical analysis of the results of identification of type I muscle fibers, intermediate and type II was carried out using dispersion analysis (Fisher's criterion (F)) based on BoxCox transformation. Assessment of the results of determining $\mathrm{pH}$ and temperature in the longissimus $45 \mathrm{~min}$ after the slaughter was conducted using the Mann-Whitney test. The relationships between the mean diameter of the fibers, length of sarcomeres and degree of expressiveness of myotypes were determined using ANOVA and Tukey test taking into account multiple-comparison correction (Bonferroni correction). Logistic regression and Spearman correlation taking into account the significance criterion $\mathrm{P}$ were used for the analysis of the interrelation between the characteristics of carcasses and microstructure of the muscle tissue. The differences were considered significant and the presence of relationship between the parameters was determined at the level of tendency that did not exceed 0.05 .

\section{Results}

According to the results of $\mathrm{pH}-$-metry of the longissimus of the carcasses $45 \mathrm{~min}$ following the slaughter, we determined carcasses that in the 
course of postmortem changes had dynamics of decreasing $\mathrm{pH}_{45}(\leq 6.0)$, the share of which in the first and the second lots accounted for $33.1 \%$ and $37.5 \%$, respectively (Table 1). In the selections of carcasses with $\mathrm{pH}_{45} \leq$ 6.0 , mean values of $\mathrm{pH}_{45}$ were lower by 0.28 and 0.26 units than in the corresponding lot. The rest of the carcasses with $\mathrm{pH}_{45}>6.0$ were classified to the meat with the normal course of autolysis. However, we observed that in the selections of carcasses with $\mathrm{pH}_{45}>6.0$, mean $\mathrm{pH}_{45}$ values were only 0.13 and 0.16 higher than in the corresponding party. Between the two lots delivered by different cars, we saw no statistically significant differences $(\mathrm{P}=0.730)$. This confirmed the homogeneity of the conditions of the experiment. The temperature in all carcasses 45 minutes postslaughter was $37^{\circ} \mathrm{C}$ higher, indicating the rhythmic pattern of conducting all the slaughter procedures, primary processing and $\mathrm{pH}$-metry. Carcasses with normal dynamics of decline in $\mathrm{pH}$ after slaughter $\left(\mathrm{pH}_{45}>6.0\right)$, selected randomly for histological studies, weighed 90 to $114 \mathrm{~kg}$. Difference in the weight of fresh carcasses was accompanied by a little more than two times difference between carcasses according to thickness of the bone marrow and the area of transversal section of longissimus (Table 2).

Table 1

Results of measuring $\mathrm{pH}$ and temperature in the longissimus 45 min following the slaughter $(\mathrm{x} \pm \mathrm{SD}, \mathrm{n}=320)$

\begin{tabular}{|c|c|c|c|c|c|c|}
\hline \multirow{2}{*}{ Показатель } & \multicolumn{3}{|c|}{1 lot of animals $(n=160)$} & \multicolumn{3}{|c|}{2 lot of animals $(n=160)$} \\
\hline & $\mathrm{x} \pm \mathrm{SD}$ & $\min -\max$ & median & $\mathrm{x} \pm \mathrm{SD}$ & $\min -\max$ & median \\
\hline $\mathrm{pH}_{45}$ value & $6.12 \pm 0.26$ & $5.38-6.86$ & 6.11 & $6.15 \pm 0.27$ & $5.37-6.89$ & 6.14 \\
\hline Temperature, ${ }^{\circ} \mathrm{C}$ & $39.0 \pm 0.7$ & $36.8-40.6$ & 39.0 & $39.3 \pm 0.9$ & $37.1-41.0$ & 39.4 \\
\hline Share of carcasses with $\mathrm{pH}_{45} \leq 6.0, \%$ & 33.1 & - & - & 37.5 & - & - \\
\hline $\mathrm{pH}_{45}$ value in carcasses with $\mathrm{pH}_{45} \leq 6.0$ & $5.84 \pm 0.17$ & $5.38-6.04$ & 5.89 & $5.89 \pm 0.16$ & $5.37-6.04$ & 5.95 \\
\hline Temperature in carcasses with $\mathrm{pH}_{45} \leq 6.0,{ }^{\circ} \mathrm{C}$ & $39.1 \pm 0.8$ & $37.0-40.4$ & 39.3 & $39.5 \pm 0.9$ & $37.1-41$ & 39.7 \\
\hline Share of carcasses with $\mathrm{pH}_{45}>6.0, \%$ & 66.9 & - & - & 62.5 & - & - \\
\hline $\mathrm{pH}_{45}$ value in carcasses with $\mathrm{pH}_{45}>6.0$ & $6.25 \pm 0.18$ & $5.99-6.86$ & 6.23 & $6.31 \pm 0.19$ & $6.06-6.89$ & 6.27 \\
\hline Temperature in carcasses with $\mathrm{pH}_{45}>6.0,{ }^{\circ} \mathrm{C}$ & $38.9 \pm 0.7$ & $36.8-40.6$ & 39.0 & $39.2 \pm 0.9$ & $37.1-41.0$ & 39.3 \\
\hline
\end{tabular}

Note: method of comparing the selections (Mann-Whitney) revealed no cases of significant differences.

Share of samples without signs of myopathy (Table 3) accounted for $44.4 \%$ of the total number of the samples ( 8 out of 18 carcasses). The samples were characterized by wavy pattern of the muscle fibers. Transversal striation was smoothened. The length of sarcomeres varied 1.35 to $1.60 \mu \mathrm{m}$. On the histological sections, there were no contracture nodes and destructive changes in the muscle fibers. The diameter of the muscle fibers depending on their type equaled 25 to $45 \mu \mathrm{m}$ (Fig. 1). The samples with mildly expressed myopathy equaled $38.9 \%$ of the general amount of carcasses ( 7 of 18 carcasses). Microstructure of the muscle tissue in such samples was characterized by mostly straight or slightly wavy muscular fibers that were lying freely in relation to one another.
Table 2

Characteristics of swine carcasses with $\mathrm{pH}_{45}>6.0$, selected randomly for histological studies $(\mathrm{x} \pm \mathrm{SD}, \mathrm{n}=18)$

\begin{tabular}{lccc}
\hline \multicolumn{1}{c}{ Parameter } & $\mathrm{x} \pm \mathrm{SD}$ & $\begin{array}{c}\text { Minimum- } \\
\text { maximum }\end{array}$ & Median \\
\hline Weight of paired carcass, $\mathrm{kg}$ & $99.28 \pm 6.74$ & $90.00-114.00$ & 97.00 \\
Thickness of the bone marrow, $\mathrm{mm}$ & $32.83 \pm 5.49$ & $20.00-41.00$ & 33.00 \\
Area of the longissimus, $\mathrm{cm}^{2}$ & $59.08 \pm 12.27$ & $36.40-77.40$ & 59.75 \\
$\mathrm{pH}_{45}$ & $6.28 \pm 0.17$ & $6.00-6.60$ & 6.23 \\
\hline
\end{tabular}

Table 3

Results of histological studies of the muscle tissue samples ( \pm SD, $n=18$ )

\begin{tabular}{|c|c|c|c|c|c|c|c|c|c|}
\hline \multirow{2}{*}{ Parameter } & \multicolumn{3}{|c|}{ With no myopathy $(\mathrm{n}=8)$} & \multicolumn{3}{|c|}{ With mildly expressed myopathy $(\mathrm{n}=7)$} & \multicolumn{3}{|c|}{ With acute myopathy $(n=3)$} \\
\hline & $\mathrm{x} \pm \mathrm{SD}$ & $\min -\max$ & median & $\mathrm{x} \pm \mathrm{SD}$ & $\min -\max$ & median & $\mathrm{x} \pm \mathrm{SD}$ & $\min -\max$ & median \\
\hline Shape of muscle fibers & \multicolumn{3}{|c|}{ wavy } & \multicolumn{3}{|c|}{ straight or slightly wavy } & \multicolumn{3}{|c|}{ straight } \\
\hline Transversal striation & \multicolumn{3}{|c|}{ smoothed } & \multicolumn{3}{|c|}{ distinct } & \multicolumn{3}{|c|}{ distinct } \\
\hline Sarcolemma condition & \multicolumn{3}{|c|}{ no destructive changes } & \multicolumn{3}{|c|}{ no destructive changes } & \multicolumn{3}{|c|}{ ruptures of sarcolemma and myofibrils } \\
\hline Length of sarcomeres, $\mu \mathrm{m}$ & $1.5 \pm 0.1$ & $1.4-1.6$ & 1.5 & $1.7 \pm 0.3^{b}$ & $1.4-2.1$ & 1.7 & $2.3 \pm 0.1^{\mathrm{a}}$ & $2.2-2.4$ & 2.4 \\
\hline Size of contracture nodes (stripes), $\mu \mathrm{m}$ & \multicolumn{3}{|c|}{ no contracture nodes (stripes) } & no & $100.0-425.0$ & 200.0 & $279.2 \pm 97.1$ & $200.0-387.5$ & 250.0 \\
\hline Diameter of contracture nodes, $\mu \mathrm{m}$ & \multicolumn{3}{|c|}{-} & - & $60.0-90.0$ & 60.0 & $113.3 \pm 11.6$ & $100.0-120.0$ & 120.0 \\
\hline Diameters of fibers, including: & & & & & & & & & \\
\hline -I (oxidative) type, $\mu \mathrm{m}$ & $25.1 \pm 0.3^{\mathrm{b}}$ & $25-26$ & 25.0 & $22.0 \pm 1.0^{\mathrm{b}}$ & $20-23$ & 22.0 & $21.7 \pm 2.9^{\mathrm{a}}$ & $20-25$ & 20.0 \\
\hline - intermediate type, $\mu \mathrm{m}$ & $35.0 \pm 0.0^{\mathrm{a}}$ & $35-35$ & 35.0 & $35.6 \pm 0.5^{\mathrm{a}}$ & $35-36$ & 36.0 & $36.0 \pm 1.0^{\mathrm{a}}$ & $35-37$ & 36.0 \\
\hline (glycolytic) type, $\mu \mathrm{m}$ & $44.4 \pm 1.7^{\mathrm{b}}$ & $40-45$ & 45.0 & $49.3 \pm 1.9^{\mathrm{a}}$ & $45-50$ & 50.0 & $48.3 \pm 7.6^{\mathrm{a}}$ & $40-55$ & 50.0 \\
\hline Share of type II fibers, $\%$ & $77.3 \pm 0.8^{\mathrm{b}}$ & $76.3-78.5$ & 76.9 & $79.4 \pm 2.4^{b}$ & $76.6-83.7$ & 78.6 & $83.3 \pm 2.1^{\mathrm{a}}$ & $81.8-85.7$ & 82.5 \\
\hline Share of intermediate type, $\%$ & $13.1 \pm 1.0^{\mathrm{b}}$ & $11.1-14.4$ & 13.4 & $12.5 \pm 2.1^{\mathrm{ab}}$ & $10.2-15.6$ & 11.9 & $9.8 \pm 1.2^{\mathrm{a}}$ & $8.5-10.5$ & 10.5 \\
\hline Share of type I type, $\%$ & $9.6 \pm 0.6^{\mathrm{b}}$ & $8.7-10.7$ & 9.5 & $8.09 \pm 1.6^{b}$ & $6.1-9.7$ & 8.1 & $7.4 \pm 1.5^{\mathrm{a}}$ & $5.8-8.8$ & 7.7 \\
\hline
\end{tabular}

Note: ${ }^{\text {a }},{ }^{\mathrm{c}}{ }^{\mathrm{c}}$ - differences between muscle tissues are significant at $\mathrm{P}<0.05$; interrelation between mean diameter of fibers, length of sarcomeres and the degree of expressiveness of myotypes was determined using ANOVA and Tukey test taking into account multiple comparisons (Bonferroni correction).
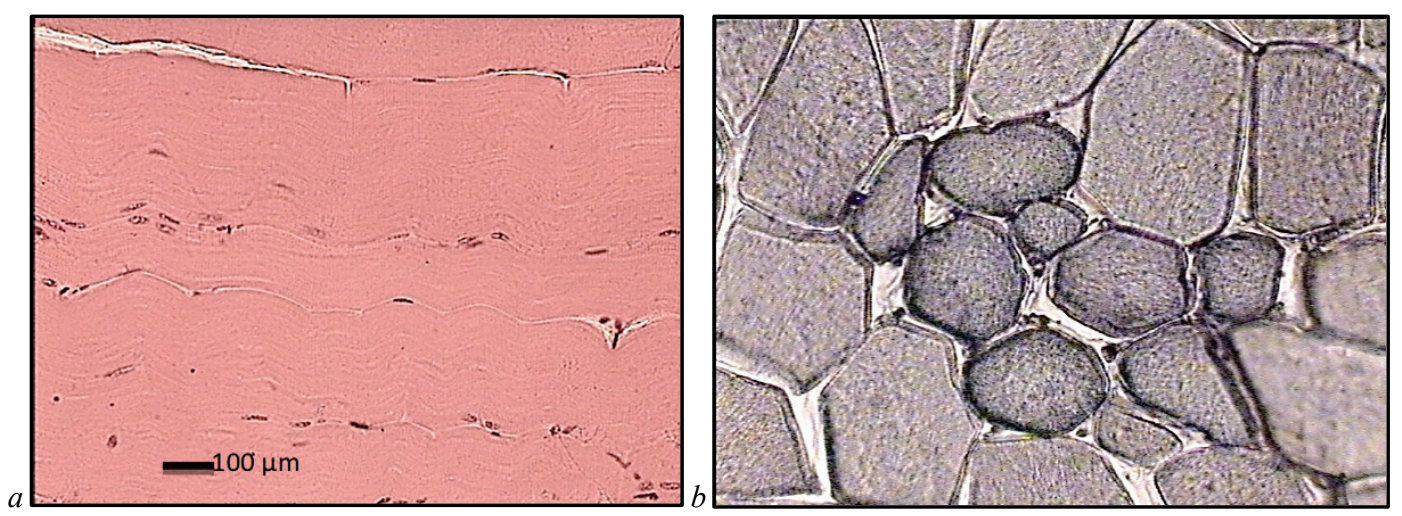

Fig. 1. Microstructure of the samples of muscular tissue with no signs of myopathy: $a$-longitudinal section; $b$-transversal section 
Transversal striation of the fibers was expressed. The diameter of the fibers ranged 25.0 to $50.0 \mu \mathrm{m}$. In deep layers of the muscles, we found 200 to $450 \mu \mathrm{m}$ long regions of the fibers with altered structure, which were characterized by singular or multiple oval-shaped contracture nodes with homogenous structure or less dense transversal striation, measuring 60 to $100 \mu \mathrm{m}$ in diameter, or multiple homogenous transversal stripes, sarcolemma maintained integrity in all cases (Fig. 2).

The share of the samples with acute myopathy accounted for $16.7 \%$ of the total number of the samples ( 3 of 18 carcasses). The muscular tissue with acute myopathy was characterized by straight muscular fibers, distinct transversal striation and multiple rectangular-shaped contracture nodes with ruptures of myofibrils in the adjacent regions, which had homogenous structure. The sizes of the contracture nodes were 100 to $450 \mu \mathrm{m}$, the diameter of the contracture nodes - from 70 to $120 \mu \mathrm{m}$. Aside from the contracture nodes, the structure of the fibers were observed to have multiple contraction stripes measuring $600-900 \mu \mathrm{m}$ to $1.5 \mathrm{~mm}$ in length, thickened, and with homogenous structure and multiple narrow gaps that had developed as a result of rupture of myofibrils and breakdown of myofibrils to fine-grained protein mass. The diameter of the fibers was 20 to $55 \mu \mathrm{m}$ depending on their type, and the length of sarcomeres -2.2 to $2.4 \mu \mathrm{m}$. Thus, in pork that was characterized by high values of $\mathrm{pH}_{45}$, the share of the samples with mild and acute myopathy equaled $55.6 \%$ (Fig. 3).

Statistically significant differences between the samples of three groups were determined according to mean length of sarcomeres $(\mathrm{P}<$ 0.05 ) and share of fibers of type II (glycolytic, $\mathrm{P}<0.05$ ). Significant differences between the group of samples with no myopathy and the groups with myopathy were determined according to all histological indicators, except the share and diameter of fibers of intermediate type. The samples with mildly expressed and acute myopathy significantly differed only by length of sarcomeres, diameter of contracture nodes and share of fibers of glycolytic type (Table 4).

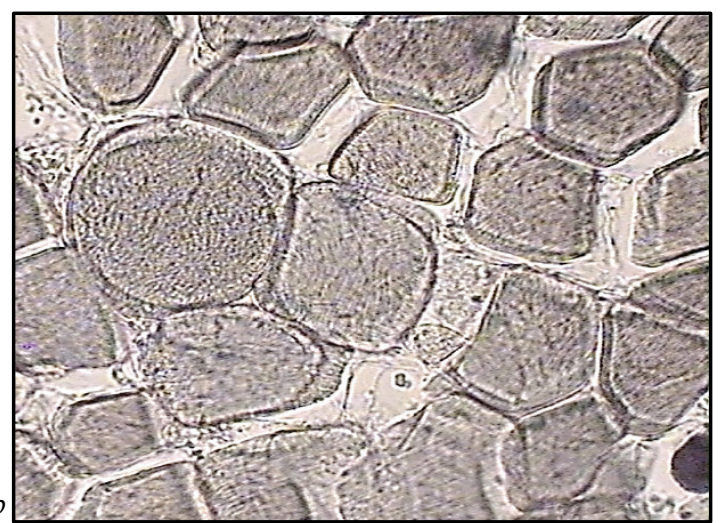

Fig. 2. Microstructure of the samples of muscular tissue with mildly expressed signs of myopathy: $a$-longitudinal section; $b$-transversal section
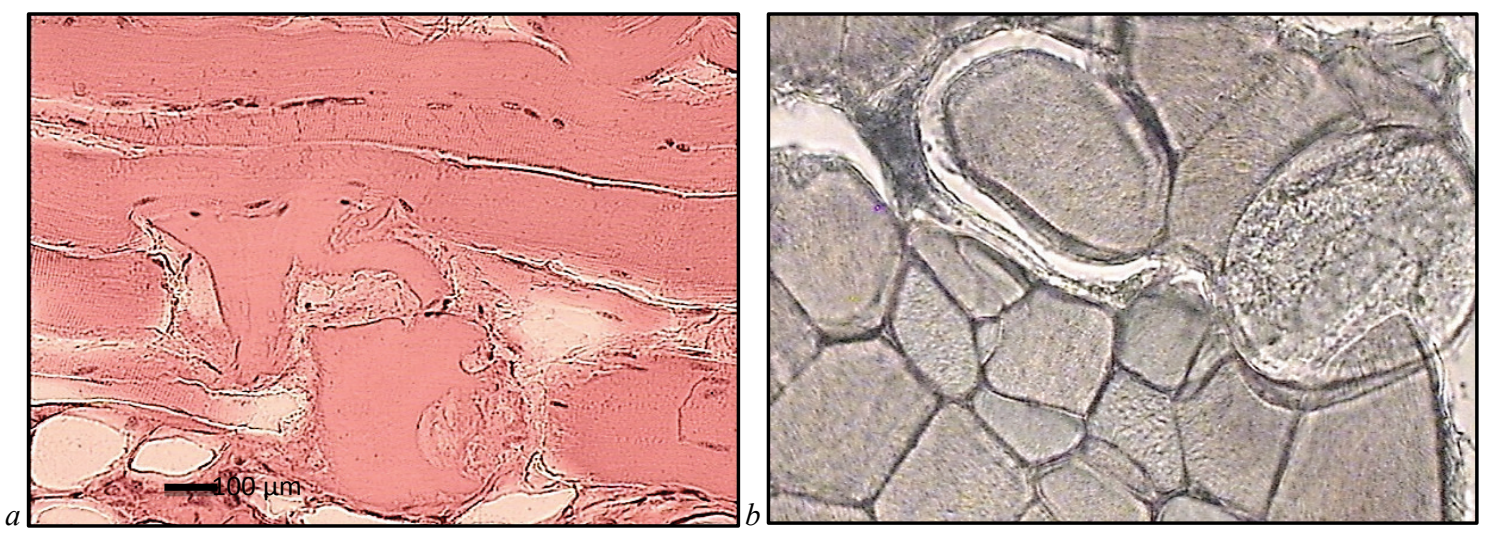

Fig. 3. Microstructure of the samples of muscular tissue with acute myopathy: $a$-longitudinal section; $b$-transversal section

Table 4

Statistical differences between the samples of three groups

\begin{tabular}{|c|c|c|c|}
\hline \multirow[b]{2}{*}{ Parameters } & \multicolumn{3}{|c|}{ P values for compared groups } \\
\hline & $\begin{array}{c}\text { no myopathy } \\
\text { vs. mildly expressed myopathy }\end{array}$ & $\begin{array}{c}\text { no myopathy } \\
\text { vs. acute myopathy }\end{array}$ & $\begin{array}{l}\text { mildly expressed myopathy } \\
\text { vs. acute myopathy }\end{array}$ \\
\hline Length of sarcomeres, $\mu \mathrm{m}$ & 0.0459 & 0.0001 & 0.0001 \\
\hline Size of contracture nodes (stripes), $\mu \mathrm{m}$ & ud & ud & 0.3925 \\
\hline Diameter of contracture nodes, $\mu \mathrm{m}$ & ud & ud & 0.0009 \\
\hline Diameter of fibers, including: & & & \\
\hline$-\mathrm{I}$ (oxidative) type, $\mu \mathrm{m}$ & 0.0003 & 0.0002 & 0.6024 \\
\hline - intermediate type, $\mu \mathrm{m}$ & 0.0976 & 0.0643 & 0.8448 \\
\hline -II (glycolytic) type, $\mu \mathrm{m}$ & 0.0190 & 0.0261 & 0.9440 \\
\hline Share of fibers of type II, $\%$ & 0.0410 & 0.0001 & 0.0160 \\
\hline Share of intermediate type fibers, $\%$ & 0.7710 & 0.0154 & 0.0613 \\
\hline Share of type I fibers, $\%$ & 0.0257 & 0.0080 & 0.5945 \\
\hline
\end{tabular}

Note: ud-undetermined.

Thus, presence and expressiveness of myopathic changes in pork with $\mathrm{pH}_{45}$ higher than 6.0 can be determined not only by size and diameters of contracture nodes (stripes), but also by length of sarcomeres, shares and diameters of types I and II fibers. This fact may be used for assessing the technological quality of carcasses. The results of regression analysis of dependencies of microstructure indicators on the characteristics of car- 
casses (Table 5) demonstrated that the greatest extent of relationship was between the diameter of fibers of glycolytic type and the weight of fresh carcass. However, only $28 \%$ of the total variability of the parameters of muscle tissue microstructure was conditioned by the variation of this carcass characteristic $\left(\mathrm{R}^{2}=0.288, \mathrm{P}=0.022\right)$.

\section{Table 5}

Assessment of influence of weight of fresh carcass, thickness of the bone marrow and area of the longissimus on the microstructure of the muscle tissue

\begin{tabular}{lccc}
\hline \multicolumn{1}{c}{$\begin{array}{c}\text { Microstructure } \\
\text { of muscle tissue }\end{array}$} & $\begin{array}{c}\text { Weight of } \\
\text { paired carcass }\end{array}$ & $\begin{array}{c}\text { Thickness of } \\
\text { bone marrow }\end{array}$ & $\begin{array}{c}\text { Area of the } \\
\text { longissimus }\end{array}$ \\
\hline $\begin{array}{l}\text { Length of sarcomeres } \\
\text { Diameter of fibers }\end{array}$ & 0.004 & 0.0001 & 0.020 \\
Type II (glycolytic) & $0.288^{*}$ & 0.004 & 0.003 \\
Diameter of intermediate type fibers & 0.001 & 0.001 & 0.079 \\
Diameter of type I (oxidative) fibers & 0.069 & 0.062 & 0.072 \\
\hline
\end{tabular}

Note: * significant at $\mathrm{P}<0.05$, regression equation; $\mathrm{R}^{2}$ - determination coefficient.

In the group of samples with acute myopathy, the effect of weight of the fresh carcass manifested more significantly (we observed increase in $\left.\mathrm{R}^{2}=0.457\right)$. In general, we saw reverse correlation $(\mathrm{r}=-0.539 . \mathrm{P}=0.020)$ between the weight of fresh carcass and diameter of glycolytic type fibers. At the same time, reverse correlation was also generally determined by relationship that was seen in samples with acute myopathy $(\mathrm{r}=-0.671$, $\mathrm{P}=0.068)$. In the conditions of mild myopathy, we observed no significant effect of weight of paired carcass on the diameter of fibers of glycolytic type.

\section{Discussion}

Górska \& Wojtysiak (2017) observed that PSE syndrome promotes pathologic alterations in meat, particularly increases the frequency of giant and atrophic fibers, which may reduce meat quality. At the same time, to identify meat with PSE syndrome, a sharp decrease in $\mathrm{pH}$ during the first hour after slaughter should be seen (Solomon et al., 1998; Cazedey et al., 2016; Trevisan \& Brum, 2020).

The study was aimed at determining histological differences in the muscular tissue samples from fresh pig carcasses with $\mathrm{pH}_{45}$ above 6.0. We determined that despite high level of $\mathrm{pH}$ after slaughter, three types of fresh carcasses could be identified according to the condition of microstructure: first - with no signs of myopathy; second - with mild myopathy, third - with acute myopathy. This is coherent with the study that concluded that $\mathrm{pH}_{45}$ value is not indicative of the quality of pig carcasses (Cazedey et al., 2016).

Presence of contracture nodes ("giant fibers") and evaluation of their sizes, according to Górska \& Wojtysiak (2017), allow one to judge the extent of destructive alterations in the muscle tissue. In the samples of the muscular tissues of different groups of samples, we also observed differences in fibers with normal diameter according to length of sarcomeres, share and diameter of types I and II muscular fibers. At the same time, the samples of muscular tissue demonstrated negative correlation between diameter of muscular fibers of type II and the weight of carcasses. Thus, increased body weight of animals was not a risk factor, but on contrary, promoted the normal development of autolysis after slaughter, without appearance of the so-called "giant fibers", development of which is characteristic of glycolytic type fibers (Lefaucheur, 2010; Górska \& Wojtysiak, 2017).

Pale soft exudative meat is related to higher degree of destruction of the myofibrils' structure (Chmiel et al., 2014). However, the destructive alterations in the muscular tissue of pork are not always associated with the development of PSE. In the study of swine legs by Eliášová et al. (2017), signs of destructive meat were found only in $44.3 \%$ of PSE samples. At the same time, regardless of this, the finished products had noticeable faults, the so-called "destructured zones".

Development of nodes and contraction stripes in the muscle tissue is an additional factor of decrease in hydrophilicity of proteins, because a part of free valencies are involved in the development of solidified protein complex with aggregation of its structures (Joo et al., 2013). The diameter of muscular fibers in swine varies widely and may reach up to $135 \mu \mathrm{m}$ and more, and the diameter of the fibers of glycolytic type is usually greater than such of fibers of intermediate and oxidative types (Elias et al., 2007).

Muscle tissue samples of swine with clear signs of myopathy were characterized by increase in the number of glycolytic type fibers compared with oxidative and intermediate types. Many authors note genetic predisposition of swine to incompatibility of sizes of fibers of various types in the muscle tissue, which negatively affects the quality of meat (Lefaucheur, 2000; Ryu et al., 2005; Elias et al., 2007; Joo et al., 2013). In our study, diameter of type II glycolytic fibers in the samples with myopathic alterations was greater, while the diameters of type I fibers was lower than in the samples where no such changes were observed. However, incompatibility was not statistically confirmed by decrease in the diameter of intermediate type.

Over the recent years, scientists have been thinking afresh on the role of the muscular tissue in the development of meat quality (Joo et al., 2013). Also, the role of connective tissue of muscle is being analyzed. Intramuscular connective tissue performs a broad range of functions, including coordination of deformation between the neighboring fibers, supports the connection of sarcomeres between one another and serves each muscular fiber. Fast growth of muscles is associated with high level of metabolism in connective tissue matrix and may lead to hypertrophy of the muscle fibers (Purslow, 2020).

Diameter of muscle fibers is one the most important characteristics of microstructure of the muscle tissue, and our study has confirmed this once again. To evaluate the functional-technological properties of pig carcasses after slaughter, new approaches will be developed. As promising directions, there are noted histological methods for dividing PSE and RSE meat, though they are not yet considered as the main methodology (Chmiel et al., 2014). The main requirements to these types of meat will be objectivity, reproductivity and fast results. Over the recent years, there has been a noticeable tendency toward the development of express methods for studying microstructural parameters, and also developing new tools that would allow efficient analysis of transversal sections of meat for the purposes of studies and diagnostics (Song et al., 2020; Stevens et al., 2020). This may likely promote changes in the approaches to choosing criteria for meat quality. Therefore, predicting technological qualities of the muscle tissue according not only to presence of "giant fibers", but also according to characteristics of normal-sized fibers would improve the objectivity. In our experiment, we did everything we could to create identical conditions for all the animals in order to obtain pork that would be of the same quality. Nonetheless, even after selecting fresh carcasses, the pork varied in microstructural characteristics according to $\mathrm{pH}$. This may indicate high variability of these characteristics under the influence of the same factors within the development of individual peculiarities of animals, starting from embryo period and birth (Gondret et al., 2006).

We should note that in the experimental conditions, the share of carcasses with drastic decrease in $\mathrm{pH}$ over the first hour after slaughter, when the temperature in the muscle layer was over $37^{\circ} \mathrm{C}$, was almost twice as high as in the study by Elias et al. (2007). This allows us to conclude about the necessity of further development of culture of animal keeping in terms of their wellbeing, including paying more attention to such factors as animals' rest time in the pens before slaughter, overall hunger time, hunger time on the farm prior to slaughter and time of transporting animals from farm to slaughter.

\section{Conclusions}

Pork that was not observed to have rapid decrease in $\mathrm{pH}$ in fresh condition is not homogenous according to microstructural characteristics, which inevitably affects the quality. Orientation to high values of $\mathrm{pH}_{45}$ when choosing pig carcasses, may lead to erroneous results in $55.6 \%$ of cases. Increase in the diameter of glycolytic type muscle fibers was related to emergence of "giant fibers". Increased weight of the animals was not a risk factor. Samples of the muscle tissue with myopathy significantly differed from the samples with no myopathy according to length of sarcomeres, share and diameter of fibers of types I and II. At the same time, the samples with acute myopathy significantly differed from the samples with mild myopathy by length of sarcomeres, diameter of contracture nodes and share of glycolytic type fibers. 
The studies were supported financially by the Russian Science Foundation (project No. 19-16-00068 "The study of the influence of alimentary factors on metabolism, slaughter characteristics and risks of myopathy in swine").

The authors claim no conflict of interests.

\section{References}

Barbut, S., Sosnicki, A. A., Lonergan, S. M., Knapp, T., Ciobanu, D. C., Gatcliffe, L. J., Huff-Lonergan, E., \& Wilson, E. W. (2008). Progress in reducing the pale, soft and exudative (PSE) problem in pork and poultry meat. Meat Science, $79(1), 46-63$.

Bickhardt, K. (1998). Exertional myopathy and osteochondrosis of pigs as a result of breeding for growth rate. Tierarztliche Umschau, 53(3), 129-134.

Cazedey, H. P., Filho, R. T., Fontes, P. R., Ramos, A. S., \& Ramos, E. M. (2016). Comparison of different criteria used to categorize technological quality of pork. Ciência Rural, 46(12), 2241-2248.

Chmiel, M., Słowiñski, M., \& Janakowski, S. (2014). The quality evaluation of RFN and PSE pork longissimus lumborum muscle considering its microstructure. Annals of Animal Science, 14(3), 737-747.

Elias, Z., Hluchy, S., \& Mlynek, J. (2007). Histological structure of the musculus longissimus lumborum et thoracis in pigs with the same ryanodine receptor genotype (CC) in relation to carcass indicators. Czech Journal of Animal Science, $52,12-20$.

Eliášová, M., Kameník, J., Saláková, A., Pavlík, Z., Pospiech, M., \& Tremlová, B. (2017). The effect of PSE and non-PSE adductor and semimembranosus pig muscles on the occurrence of destructured zones in cooked hams. Journal of Food Quality, 10, 6305051.

Fiedler, I. K., Wicke, M. S., Maak, G. V., \& Meyer, L.W. (1999). Structural and functional characteristics of muscle fibres in pigs with different malignant hyperthermia susceptibility (MHS) and different meat quality. Meat Science, 53(1), 9-15.

Gondret, F., Lefaucheur, L., Juin, H., Louveau, I., \& Lebret, B. (2006). Low birth weight is associated with enlarged muscle fiber area and impaired meat tenderness of the longissimus muscle in pigs. Journal of Animal Science, 84(1), 93-103.

Górska, M., \& Wojtysiak, D. (2017). Pathological changes in the microstructure of pale. soft. exudative (PSE) and normal turkey breast muscle. Folia Biologica, 65(3), 149-154.

Honkavaara, M. (1988). Influence of PSE pork on the quality and economics of cooked, cured ham and fermented dry sausage manufacture. Meat Science, 24(3), 201-207.

Joo, S. T., Kim, G. D., Hwang, Y. H., \& Ryu, Y. C. (2013). Control of fresh meat quality through manipulation of muscle fiber characteristics. Meat Science, 95(4), 828-836.

Keenan, D. F. (2016). Pork meat quality, production and processing on. In: Caballero, B., Finglas, P. M., \& Toldra, F. (Eds.). Encyclopedia of food and health. Academic Press. Pp. 419-431.

Kim, Y. H. B., Warner, R. D., \& Rosenvold, K. (2014). Influence of high pre-rigor temperature and fast $\mathrm{pH}$ fall on muscle proteins and meat quality: A review. Animal Production Science, 54(4), 375-395.

Kovalenko, V. A., Gilman, Z. D., \& Orlova, A. S. (1987). Metodicheskie rekomendacii po ocenke myasnoj produktivnosti, kachestva myasa i podkozhnogo zhira svinej [Methodological recommendations for the assessment of meat productivity, quality of meat and subcutaneous fat of pigs]. All-Russin Academy of Agricultural Sciences, Moscow (in Russian).

Lefaucheur, L. (2010). A second look into fibre typing. Relation to meat quality. Meat Science, 84(2), 257-270.

Li, Y. X., Cabling, M. M., Kang, H. S., Kim, T. S., Yeom, S. C., Sohn, Y. G., Kim, S. H., Nam, K. C., \& Seo, K. S. (2013). Comparison and correlation analysis of different swine breeds meat quality. Asian Australasian Joumal of Animal Sciences, 26(7), 905-910.

Neethling, N. E., Suman, S. P., Sigge, G. O., Hoffman, L. C., \& Hunt, M. C. (2017). Exogenous and endogenous factors influencing color of fresh meat from ungulates. Meat and Muscle Biology, 1(1), 253-275.

Nekrasov, R. V., Golovin, A. V., Machaev, E. A., Anikin, A. S., Pervov, N. G., Strekozov, N. I., Mysik, A. T., Duborezov, V. M., Chabaev, M. G., Fomichev, Y.P., \& Gusev, I. V. (2018). Normy potrebnostej molochnogo skota i svinej v pitatel'nyh veshchestvah [Requiments of nutrition of dairy cattle and pigs]. Russian Academy of Sciences, Moscow (in Russian).

OECD/FAO (2021). OECD-FAO Agricultural Outlook 2021-2030. OECD Publishing, Paris

O'Neill, D. J., Lynch, P. B., Troy, D. J., Buckley, D. J., \& Kerry, J. P. (2003). Effects of PSE on the quality of cooked hams. Meat Science, 64(2), 113-118.

Ovsyannikov, A. I. (1976). Osnovy opytnogo dela v zhivotnovodstve [Fundamentals of experimental in animal husbandry]. Kolos, Moscow (in Russian).

Owen, L. B., Montgomery, L. J., Ramsey, B. C., \& Miller, M. F. (2000). Preslaughter resting and hot-fat trimming effects on the incidence of pale, soft and exudative (PSE) pork and ham processing characteristics. Meat Science, 54(3), 221-229.

Purslow, P. P. (2020). The structure and role of intramuscular connective tissue in muscle function. Frontiers in Physiology, 11, 495.

Rosenvold, K., \& Andersen, H. J. (2003). Factors of significance for pork quality. A review. Meat Science, 64(3), 219-237.

Ryu, Y. C., \& Kim, B. C. (2005). The relationship between muscle fiber characteristics, postmortem metabolic rate and meat quality of pig longissimus dorsi muscle. Meat Science, 71(2), 351-357.

Sandercock, D. A., Hunter, R. R., Nute, G. R., Mitchell, M. A., \& Hocking, P. M. (2001). Acute hear stress-induced alterations in blood acid-base status and skeletal muscle membrane integrity in broiler chickens at two ages: Implications for meat quality. Poultry Science, 80(4), 418-425.

Saprykin, V. P., \& Turbin, D. A. (1997). Osnovy morfologicheskoj diagnostiki zabolevanij skeletnyh myshc [Fundamentals of morphological diagnosis of skeletal muscle diseases]. Moscow (in Russian).

Schubert-Schoppmeyer, A., Fiedler, I., Nurnberg, G., Jonas, L., Ender, K., Maak, S., $\&$ Rehfeldt, C. (2008). Simulation of giant fibre development in biopsy samples from pig longissimus muscle. Meat Science, 80(4), 1297-1303.

Shen, L., Lei, H., Zhang, S., Li, X., Li, M., Jiang, X., Zhu, K., \& Zhu, L. (2014). The comparison of energy metabolism and meat quality among three pig breeds. Journal of Animal Science, 85, 770-779.

Solomon, M. B., Van Laack, R. L. J. M., \& Eastridge, J. S. (1998). Biophysical basis of pale, soft, exudative (PSE) pork and poultry muscle: A review. Journal of Muscle Foods, 9, 1-11.

Song, S., Ahn, C.-H., \& Kim, G.-D. (2020). Muscle fiber typing in bovine and porcine skeletal muscles using immunofluorescence with monoclonal antibodies specific to myosin heavy chain isoforms. Food Science of Animal Resources, 40(1), 132-144.

Sosnicki, A. (1987). Histopathological observation of stress myopathy in M. longissimus in the pig and relationships with meat quality, fattening and slaughter traits. Journal of Animal Science, 65(2), 584-596.

Stevens, C. R., Berenson, J., Sledziona, M., Moore, T. P., Dong, L., \& Cheetham, J. (2020). Approach for semi-automated measurement of fiber diameter in murine and canine skeletal muscle. PLoS One, 15(12), e0243163.

Trevisan, L., \& Brum, J. (2020). Incidence of pale, soft and exudative (PSE) pork meat in reason of extrinsic stress factors. Anais da Academia Brasileira de Ciecias, 92(3), e20190086.

Van de Perre, V., Ceustermans, A., Leyten, J., \& Geers, R. (2010). The prevalence of PSE characteristics in pork and cooked ham-effects of season and lairage time. Meat Science, 86(2), 391-397. 